\title{
Lipocalin-Type Prostaglandin D Synthase ( $\beta$-Trace) Is Located in Pigment Epithelial Cells of Rat Retina and Accumulates within Interphotoreceptor Matrix
}

\author{
Carsten T. Beuckmann, ${ }^{1}$ William C. Gordon, ${ }^{2}$ Yoshihide Kanaoka, ${ }^{1}$ Naomi Eguchi, ${ }^{3}$ Victor L. Marcheselli, ${ }^{2}$ \\ Dimitry Y. Gerashchenko, ${ }^{1}$ Yoshihiro Urade, ${ }^{1}$ Osamu Hayaishi, ${ }^{1}$ and Nicolas G. Bazan² \\ ${ }^{1}$ Department of Molecular Behavioral Biology, Osaka Bioscience Institute, Suita Osaka 565, Japan, 2Louisiana State \\ University Medical Center, Neuroscience Center and Department of Ophthalmology, New Orleans, Louisiana 70112, and \\ 3Precursory Research for Embryonic Science and Technology, Research Development Corporation of Japan, \\ Suita Osaka 565, Japan
}

Glutathione-independent prostaglandin D synthase, identical to $\beta$-trace, (a major CSF protein), is localized in the CNS. This enzyme, lipocalin-type prostaglandin D synthase, is a member of the lipocalin family of secretory proteins that transport small lipophilic substances. This enzyme's activity in adult rat retina was enriched sixfold in retinal pigment epithelium (RPE) and even more in interphotoreceptor matrix (IPM), all higher than brain. Western blots with anti-lipocalin-type prostaglandin $D$ synthase showed three distinct immunoreactive bands. In the retinal cytosolic fraction, only one band was observed $\left(M_{r}\right.$ $25,000)$; in IPM, the larger component occurred $\left(M_{r} 26,000\right)$. The RPE membrane-bound fraction showed two bands $\left(M_{r}\right.$ 20,000 and 23,000), indicating synthesis, and the cytosolic fraction contained two bands $\left(M_{r} 23,000\right.$ and 26,000), indicating modification for release into IPM. At least two glycosylation sites occurred on the prostaglandin D synthase moiety, ex- plaining the three immunoreactive bands in Western blots. Immunohistochemistry with polyclonal antibodies against this lipocalin-type enzyme showed intense localization in RPE, but less in photoreceptor outer and inner segments. In situ hybridization showed mRNA specifically expressed in RPE. Thus, lipocalin-type prostaglandin D synthase is predominantly expressed in RPE and actively accumulated in IPM. This may demonstrate gene sharing because, while catalyzing prostaglandin $D_{2}$ synthesis, it may perform an additional, unrelated role in IPM. This enzyme is secreted from the RPE into IPM from which it is then taken up by photoreceptors. However, the nature of its ligand(s) is not known; they may be retinoids and/or docosahexanoic acid.

Key words: immunohistochemistry; interphotoreceptor matrix; lipocalin-type prostaglandin $D$ synthase; prostaglandin $D_{2}$; retina; retinal pigment epithelium
Prostaglandin (PG) $\mathrm{D}_{2}$ modulates several functions in the CNS, such as sleep-wake behavior, body temperature, luteinizing hormone release, and odor responses (Hayaishi, 1991). Among several enzymes that catalyze the isomerization of $\mathrm{PGH}_{2}$ to $\mathrm{PGD}_{2}$ (Urade et al., 1995b), glutathione-independent PGD synthase ([5Z, 13E]-[15S]-9 $\alpha$, $11 \alpha$-epidioxy-15-hydroxyprosta-5,13-dienoate D-isomerase, EC 5.3.99.2) is responsible for the production of $\mathrm{PGD}_{2}$ in brain (Urade et al., 1985), epididymis (Ujihara et al., 1988), cochlea (Tachibana et al., 1987), and retina (Goh et al., 1987). This lipocalin-type PGD synthase, a $26 \mathrm{kDa}$ glycoprotein (Urade et al., 1989), is a member of the lipocalin gene family, a group of secretory proteins and hydrophobic molecule transporters (Nagata et al., 1991) such as $\beta$-lactoglobulin and retinol-binding protein.

The lipocalin-type PGD synthase, the only member of the lipocalin family (Nagata et al., 1991) that has been shown to have enzymatic activity, has been localized to the leptomeninges, choroid plexus, and oligodendrocytes in brain and spinal cord (Urade et al., 1987, 1993). This enzyme also shares characteristics similar to other lipocalins: it is secreted into the CSF (Clausen, 1961) and binds retinoids with affinities similar to those of other lipocalins

\footnotetext{
Received May 10, 1996; revised July 9, 1996; accepted July 17, 1996.

This work was supported by National Institutes of Health Grant EY05121.

Correspondence should be addressed to Nicolas G. Bazan, Louisiana State University Medical Center, Neuroscience Center, 2020 Gravier Street, Suite B, New Orleans, LA 70112.

Copyright (C) 1996 Society for Neuroscience $0270-6474 / 96 / 166119-06 \$ 05.00 / 0$
}

such as retinol- and retinoic acid-binding protein (Tanaka et al., 1995). Thus, this enzyme is predicted to be bifunctional, acting as a $\mathrm{PGD}_{2}$-producing enzyme as well as an intercellular transporter of retinoids or other lipophilic substances. In fact, this may represent another example of gene sharing in which a gene sequence codes for a protein that serves two completely different functions (Piatigorsky et al., 1988; Urade et al., 1995a). For example, in the case of crystallins, several metabolic enzymes can also function as structural components in the lens (Piatigorsky and Wistow, 1989). However, a bifunctional nature of lipocalin-type PGD synthase in the CNS remains to be demonstrated.

$\mathrm{PGD}_{2}$ is the major prostaglandin formed in the eye (Goh et al., 1987). Also, lipocalin-type PGD synthase has been detected in retina (Goh et al., 1987), and mRNA for the human $\mathrm{PGD}_{2}$ receptor was recently found to be highly expressed in retina (Boie et al., 1995). This suggests that $\mathrm{PGD}_{2}$ is actively involved in retinal function. Thus, the retina may be used to study the functional significance and regulatory mechanisms of $\mathrm{PGD}_{2}$ and lipocalintype PGD synthase.

In this study, we investigate the cellular localization of lipocalintype PGD synthase in retina and show that this enzyme is predominantly produced in retinal pigment epithelium (RPE), and that it accumulates in the interphotoreceptor matrix (IPM). Moreover, lipocalin-type PGD synthase is also found in photoreceptors, whereas its mRNA is present only in RPE cells. Together, 
these results suggest that RPE-secreted lipocalin-type PGD synthase in the IPM is subsequently taken up by photoreceptors.

Portions of this work have appeared in abstract form (Gordon et al., 1996; Marcheselli et al., 1996).

\section{MATERIALS AND METHODS}

Tissues. Male and female adult rats (Sprague Dawley and Long-Evans; 225-300 gm) were decapitated under deep ether anesthesia. Eyes were collected on ice, anterior segments and lenses were quickly removed, and vitreous was drained.

For Western blot analyses, retinas and RPE were obtained from Long-Evans pigmented rats because RPE cells can be visualized during the separation process. Retinas were removed from eyecups and incubated in buffer containing (in mM): 50 Tris- $\mathrm{HCl}, \mathrm{pH} 7.4,2$ EGTA, 2 $\mathrm{MgCl}_{2}$, and 250 sucrose at $37^{\circ} \mathrm{C}$ for $40 \mathrm{~min}$. Retinas $(n=5$ per sample point) were gently separated from RPE cells and then homogenized in $300 \mu \mathrm{l}$ of the same buffer. RPE and the soluble components of IPM were separated by centrifugation of the incubation medium at $10,000 \times g$ for $10 \mathrm{~min}$. The pellet obtained here was combined with the pellet from the next centrifugation step, and then resuspended for the membrane-bound fraction. The supernatants were centrifuged at $100,000 \times g$ for $30 \mathrm{~min}$, and the fluids obtained constituted the soluble fraction or cytosol.

For histological studies, eyecups $(n=12)$ from albino Sprague Dawley rats were fixed at $4^{\circ} \mathrm{C}$ for $5 \mathrm{hr}$ in PBS containing $4 \%(\mathrm{w} / \mathrm{v})$ paraformaldehyde. Tissue was then cryoprotected with PBS containing $30 \%(\mathrm{w} / \mathrm{v})$ sucrose at $4^{\circ} \mathrm{C}$ for $3 \mathrm{hr}$, cut into halves along the optic nerve, embedded in ornithine carbamoyl transferase compound, and frozen on dry ice. Cryosections of $20 \mu \mathrm{m}$ thickness were cut, mounted onto poly-L-lysinecoated or gelatin-subbed glass slides, and stored at $-80^{\circ} \mathrm{C}$ until used for immunohistochemistry and in situ hybridization.

Immunohistochemistry. All dilutions were made in PBS containing $0.3 \%$ Triton X-100 (Sigma) and 10\% normal sheep serum (Chemicon). Sections were incubated with $10 \%$ normal sheep serum at $25^{\circ} \mathrm{C}$ for $1 \mathrm{hr}$ and subsequently with polyclonal rabbit anti-rat brain PGD synthase serum (1:5000 dilution) (Urade et al., 1985) at $25^{\circ} \mathrm{C}$ overnight. Controls were made with normal rabbit serum or antiserum preabsorbed with excess amounts of recombinant rat brain PGD synthase (Urade et al., 1995a). Tissue sections were next incubated with anti-rabbit serum or antiserum preabsorbed with excess amounts of recombinant rat brain PGD synthase (Urade et al., 1995a), then were treated with anti-rabbit $\operatorname{IgG~F}(\mathrm{ab})_{2}$ fragments $(20 \mu \mathrm{m} / \mathrm{ml})$ coupled with fluorescein or rhodamine (Boehringer Mannheim) at $25^{\circ} \mathrm{C}$ for $2 \mathrm{hr}$. Sections were examined in bright field by Nomarski differential interference contrast and with epifluorescence microscopy (Nikon Optiphot-2, Melville, NY; Olympus IX70, Tokyo, Japan) or by confocal laser scanning microscopy (MCR 600, Bio-Rad).

Western blotting. Tissues $(n=5$ retinas per sample) were homogenized in PBS with glass Potter homogenizers, and the soluble fraction was collected by centrifugation of homogenates at $100,000 \times \mathrm{g}$ for $30 \mathrm{~min}$. The cytosolic fraction was incubated with an excess amount of antibody at $4^{\circ} \mathrm{C}$ overnight to collect the immunoreactive protein (Urade et al., 1985). The immune complex was then recovered by incubation with protein A-Cellulofine $(10 \mu \mathrm{l})$ (Chisso, Kumamoto, Japan) at $25^{\circ} \mathrm{C}$ for $2 \mathrm{hr}$, solubilized in $1 \%$ SDS, and applied to SDS-PAGE.

In experiments for the hydrolysis of asparagine-linked oligosaccharides of this enzyme by $N$-glycanase, the immune complex was boiled for $5 \mathrm{~min}$ in $10 \mu \mathrm{l} 0.55 \mathrm{~m}$ sodium phosphate, $\mathrm{pH} 8.6,0.5 \%$ SDS, and $50 \mathrm{~mm}$ $\beta$-mercaptoethanol. After addition of $5 \mu \mathrm{l} 7.5 \% \mathrm{NP}-40$ and $15 \mu \mathrm{l}$ distilled water, samples were incubated at $37^{\circ} \mathrm{C}$ for 15 and $40 \mathrm{hr}$ with $1 \mathrm{U}$ of $\mathrm{N}$-glycanase (EC 3.5.2.52, Genzyme, Cambridge, MA; $250 \mathrm{U} / \mathrm{ml}$ ) (Urade et al., 1989). Samples were then mixed with $60 \mathrm{~mm}$ Tris-HCl, pH 6.8, $2 \%$ SDS, $10 \%$ glycerol, and $0.05 \%$ bromophenol blue and then withdrawn for SDS-PAGE.

Proteins separated in the gels were electrophoretically transferred to a PVDF membrane (Millipore) at $200 \mathrm{~mA}$ at $4^{\circ} \mathrm{C}$ for $2 \mathrm{hr}$. The membrane blot was incubated with $20 \mathrm{~mm}$ Tris- $\mathrm{HCl}, \mathrm{pH} 7.5,0.15 \mathrm{M}$ sodium chloride, $0.05 \%$ Tween $20,0.1 \%$ gelatin, and $0.1 \%$ sodium azide at $25^{\circ} \mathrm{C}$ for $1 \mathrm{hr}$ to block nonspecific binding sites, followed at $4^{\circ} \mathrm{C}$ overnight with biotinylated anti-rat brain PGD synthase IgG. After washing 3 times in $0.2 \mathrm{M}$ Tris- $\mathrm{HCl}, \mathrm{pH} 7.5,1 \mathrm{~m}$ sodium chloride, $0.1 \%$ sodium azide, and $0.05 \%$ Tween 20 , the membrane was incubated at $25^{\circ} \mathrm{C}$ for $2 \mathrm{hr}$ with alkaline phosphatase-conjugated streptavidin (1:1000 dilution, Zymed, San Francisco, CA). After washing the membrane as described above, the immunoreactivity on the blot was visualized with $20 \mu \mathrm{M}$ 5-bromo-4-chloro-3- indoylphosphate, $p$-toluidine salt (Wako, Kyoto, Japan), and $20 \mu \mathrm{M}$ nitroblue tetrazolium (Wako) in $0.1 \mathrm{M}$ Tris- $\mathrm{HCl}, \mathrm{pH} 9.5,0.1 \mathrm{M} \mathrm{NaCl}$, and $5 \mathrm{mM} \mathrm{MgCl}_{2}$.

Measurement of enzyme activity. PGD synthase activity was determined with $40 \mu \mathrm{M}\left[1-{ }^{14} \mathrm{C}\right] \mathrm{PGH}_{2}$ in the presence of $1 \mathrm{~mm}$ dithiothreitol (Urade et al., 1985), except when otherwise stated. Protein concentration was determined by the method of Lowry et al. (1951) as modified by Bensadoun and Weinstein (1976) using bovine serum albumin as a standard.

Northern blot analysis. Tissues ( $n=5$ retinas per sample) were homogenized in Isogen solution (Nippon Gene, Tokyo, Japan). Total RNA was extracted from the homogenates according to Chomczynski and Sacchi (1987), electrophoresed in $1.5 \%$ agarose gel, and transferred to a Biodyne Transfer Membrane (Pall Ultrafine Filtration). The membrane was hybridized with cDNA fragments of rat brain PGD synthase (lipocalin-type PGD synthase, accession No. J04488), rat spleen PGD synthase (hematopoietic PGD synthase, accession No. D82071), and human glyceraldehyde-3phosphate dehydrogenase (GAPDH, accession No. M33197), which were labeled with $\alpha^{32} \mathrm{P}$-deoxycytosine triphosphate using a Multi Primer Labeling Kit (Amersham, Buckinghamshire, UK).

In situ hybridization. A 567 bp fragment corresponding to positions 40-606 of the cDNA for rat brain PGD synthase was subcloned into pBluescript II $\mathrm{KS}(+)$ vector. For in vitro transcription, template DNA was linearized with HindIII (for the antisense probe) or EcoRI (for the sense probe). Probes were labeled with 11-digoxigenin-uridine triphosphate (Boehringer Mannheim) using a Gemini System II kit (Promega). Retinal sections were fixed and acetylated as reported previously (Urade et al., 1993). Sections were hybridized at $50^{\circ} \mathrm{C}$ overnight with digoxigeninlabeled antisense or sense RNA probes $(100 \mathrm{ng} / \mu \mathrm{l})$. After treatment with RNase A $(40 \mu \mathrm{g} / \mathrm{ml})$ at $37^{\circ} \mathrm{C}$ for $6 \mathrm{~min}$, the RNA probe bound to the tissue was visualized by immunostaining with a digoxigenin detection kit (Boehringer Mannheim).

\section{RESULTS}

\section{Immunohistochemical localization of the lipocalin-type PGD synthase in rat retina}

The cellular localization of lipocalin-type PGD synthase was examined in the retina of adult rats by immunofluorescence staining with polyclonal antibodies against this enzyme (Fig. 1). Immunofluorescence was clearly observed in RPE and photoreceptor outer segments, but not in other retinal regions (Fig. 1A,B,E,F). No positive fluorescence was detected when we used normal rabbit serum, antibodies against hematopoietic PGD synthase, or the anti-lipocalin-type PGD synthase serum preabsorbed with excess amounts of the recombinant enzyme (data not shown). Higher magnification revealed that immunofluorescence was distributed throughout the cytoplasm of the epithelial cells, outlining each nucleus (Fig. 1C), and confocal laser scanning microscopy demonstrated that these positive signals were located in the perinuclear regions and in distinct domains within the cytoplasm (Fig. 1D). Weak immunofluorescence was also detected in outer and inner segments of photoreceptor cells (Fig. 1E,F). The lipocalin-type PGD synthase mRNA was localized in RPE cells by in situ hybridization with digoxigenin-labeled antisense RNA (Fig. $1 G)$. Control sections incubated with sense RNA did not show positive staining in RPE cells (Fig. $1 H$ ).

\section{Biochemical and molecular biological characterization of PGD synthase in retina}

When PGD synthase distribution levels in rat ocular tissues were studied, the largest accumulation (Fig. 2) was found in the IPM soluble fraction, followed by the RPE cytosolic fraction. Western blot analysis with polyclonal antibodies against PGD synthase demonstrated a twofold increase per milligram of total protein between the IPM and the RPE soluble fractions, and an eightfold increase between the soluble and membrane-bound fractions of RPE. In retina, levels were very low, remaining about the same between the two fractions.

Interestingly, when PGD synthase activity was measured, even 


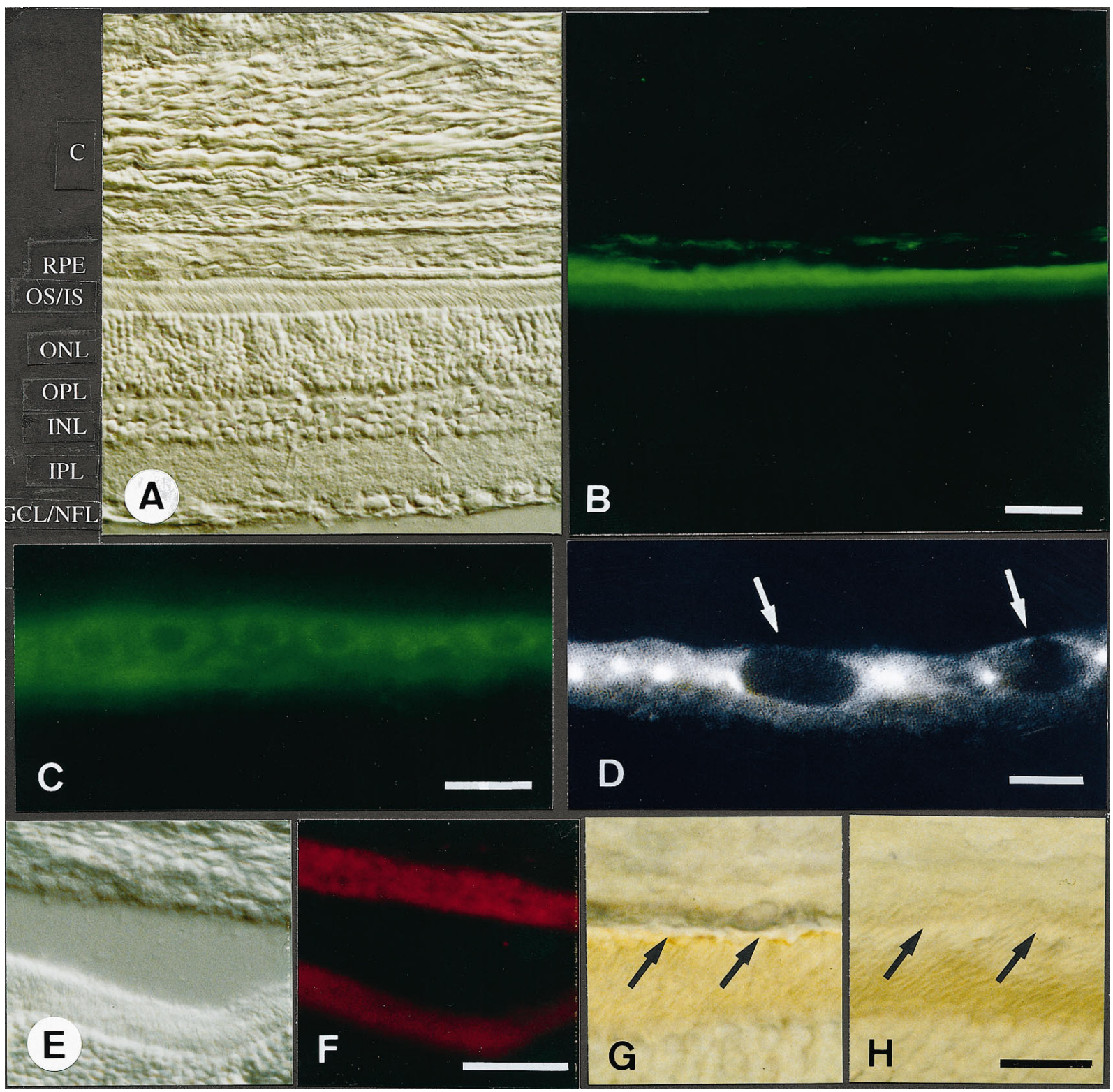

Figure 1. Detection of lipocalin-type PGD synthase-immunoreactive protein $(A-F)$ and its mRNA $(G, H)$ in rat retina. $A$, Nomarski differential interference contrast micrograph. $C$, Choriocapillaris; $R P E$, retinal pigment epithelium; $O S / I S$, outer segments/inner segments; $O N L$, outer nuclear layer; $O P L$, outer plexiform layer; $I N L$, inner nuclear layer; $I P L$, inner plexiform layer; $G C L / N F L$, ganglion cell layer/nerve fiber layer. $B$, Immunofluorescence micrograph of $A$ with anti-lipocalin-type PGD synthase antiserum, detecting immunoreactivity in RPE cells and photoreceptor outer segments (green band). Scale bar, $50 \mu \mathrm{m}$. $C$, Fluorescence micrograph of immunoreactive RPE cells at higher magnification (green band). Note typical cuboidal shape of RPE cells. Scale bar, $20 \mu \mathrm{m}$. $D$, Confocal laser scanning micrograph of immunoreactive RPE cells. Immunoreactivity is localized to the perinuclear space and distinct domains within the cytoplasm (bright white spots). Cell nuclei are dark ellipsoids (arrows). Scale bar, $5 \mu \mathrm{m}$. E, Nomarski differential interference contrast micrograph. RPE cell layer (above) and photoreceptor layer (below) are separated mechanically. $F$, Fluorescence micrograph of $E$ showing the presence of lipocalin-type PGD synthase immunoreactivity in both RPE cells and photoreceptors (red bands). Scale bar, $50 \mu \mathrm{m}$. $G$, In situ hybridization with digoxigenin-labeled antisense RNA for this enzyme. mRNA for lipocalin-type PGD synthase is detected in RPE cells (dark band above arrows), but not within photoreceptors. $H$, Hybridization with digoxigenin-labeled sense RNA to label nonspecific background. No positive signal was detected. RPE cells are located just above arrows. Scale bar, $20 \mu \mathrm{m}$.

higher activity was detected in IPM $\left(9.3 \mathrm{nmol} \cdot \mathrm{min}^{-1} \cdot \mathrm{mg}^{-1}\right.$ of protein) compared with the RPE soluble fraction (3.5 $\mathrm{nmol} \cdot \min ^{-1} \cdot \mathrm{mg}^{-1}$ protein). However, retina demonstrated very low PGD synthase activity $\left(0.58 \mathrm{nmol} \cdot \mathrm{min}^{-1} \cdot \mathrm{mg}^{-1}\right.$ protein). Moreover, it is important to note that ocular tissue expresses a fivefold higher activity for PGD synthase than brain tissue.

Western blots demonstrated consistent immunoreactivity of the polyclonal antibody in association with three, tightly colocalized bands (Fig. 3), suggesting that the PGD synthase moiety can undergo glycosylation (Urade et al., 1989). The distribution of PGD synthase-immunoreactive protein between the three bands was noticeably different when retina, IPM, and RPE soluble and membrane-bound fractions were compared. The IPM, which is a soluble fraction, demonstrated components of the three bands, but the heaviest, the most highly glycosylated form, was the most enriched (Fig. 3). A sizeable amount of this heavy band was also found in the cytosolic fraction of RPE cells. The medium-weight 


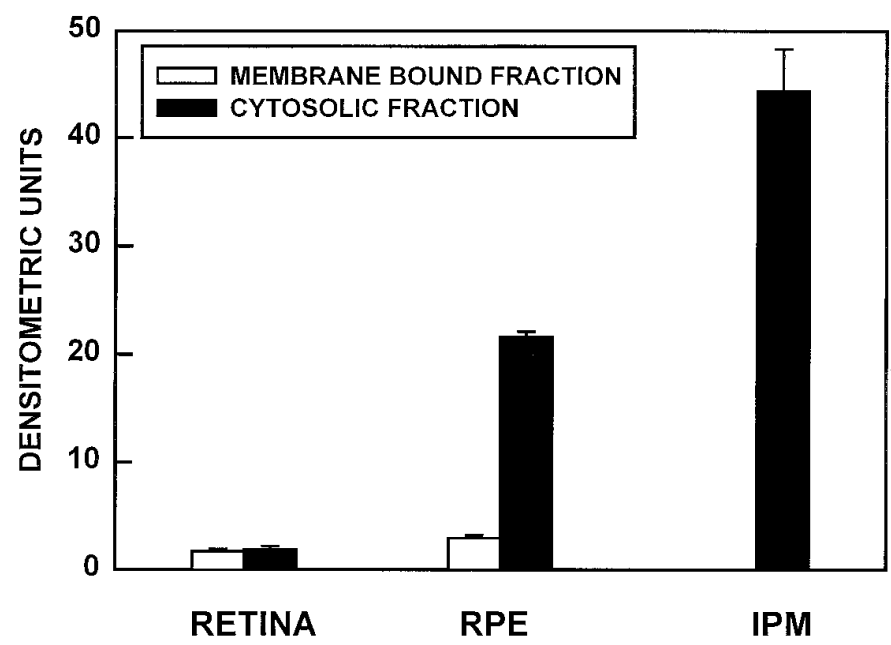

Figure 2. PGD synthase protein distribution levels in rat retina (RETINA), retinal pigment epithelium (RPE), and interphotoreceptor matrix (IPM). Homogenates from retina and RPE were spun at $100,000 \times g$ for $30 \mathrm{~min}$. The pellet contained a membrane-bound fraction, and supernatants contained the soluble fraction. Separate samples from four individuals were analyzed by Western blot. Data shown are average \pm SD.

band was the most abundant component in both the cytosolic and membrane-bound fractions of RPE (Fig. 3). In retina, both fractions contained only the medium-weight band. To correlate the mobility shifts of the immunoreactive proteins with degrees of glycosylation, IPM and retina were incubated with $N$-glycanase for different lengths of time. After $15 \mathrm{hr}$ of treatment, bands appearing at $M_{\mathrm{r}} 25,000$ and 26,000 shifted partially to $M_{\mathrm{r}} 20,000$ and $M_{\mathrm{r}}$ 23,000 (Fig. 4). After $40 \mathrm{hr}$, both retina and IPM showed these bands reduced to $M_{\mathrm{r}} 20,000$. These results indicate that the immunoreactive protein is $N$-glycosylated in at least two positions, which is also consistent with the properties of the enzyme purified from rat brain (Urade et al., 1989). Additionally, no immunoreactivity was observed in retinal extracts or IPM (data not shown) when antibodies against the hematopoietic-type PGD synthase were used (Urade et al., 1989).

Northern blot analysis of whole retina (retina plus RPE) revealed that mRNA for lipocalin-type PGD synthase also existed in this tissue (Fig. 5B). An 850 bp cDNA probe hybridized with RNA from the retina, demonstrating the presence of lipocalin-type

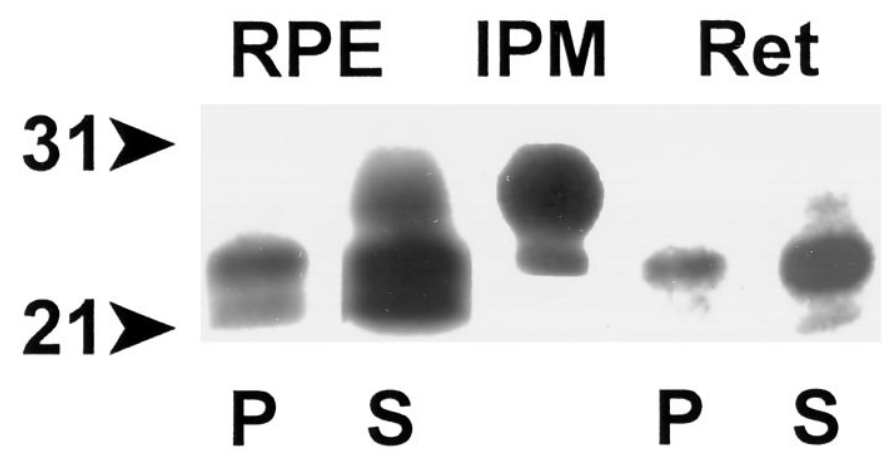

Figure 3. This representative Western blot of PGD synthase shows the distribution of three immunoreactive bands within the retinal pigment epithelium $(R P E)$, the interphotoreceptor matrix $(I P M)$, and retina $(R e t)$ in the membrane-bound (pellet) $(P)$ and the soluble $(S)$ fraction from the cytosol. The positions of two molecular markers (31 and $21 \mathrm{kDa})$ are indicated at left.

\section{R IPM R IPM R IPM}

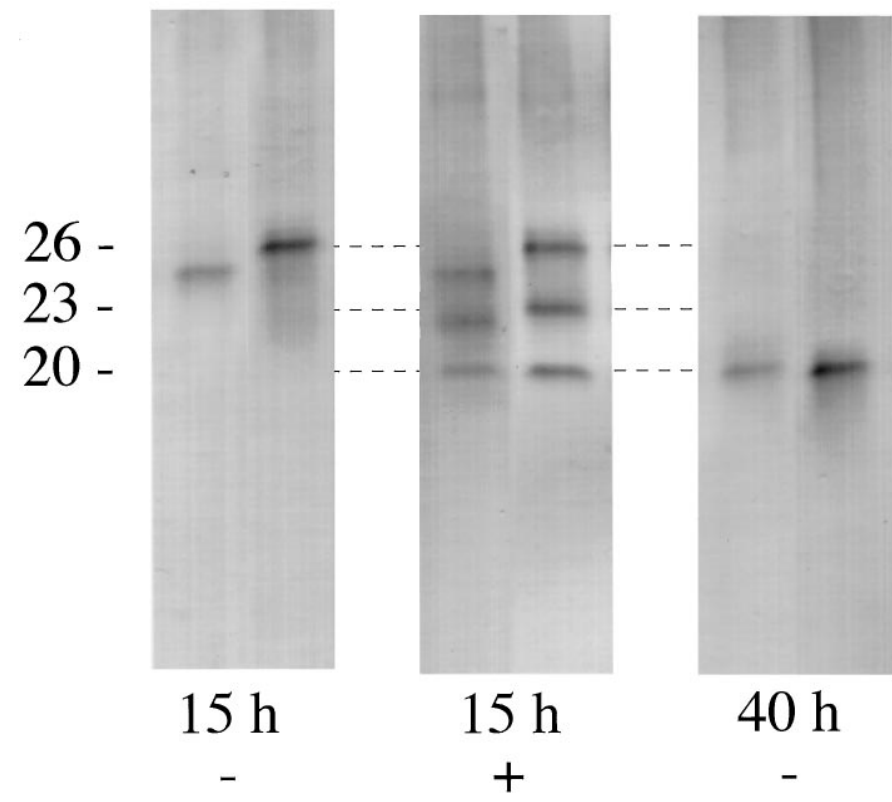

\section{$N$-Glycanase}

Figure 4. Western blot analysis of lipocalin-type PGD synthase after SDS-PAGE. Lipocalin-type PGD synthase-immunoreactive proteins were recovered from retinal cytosol fraction $(R)$ and $I P M$. Proteins were incubated in the presence and absence of $N$-glycanase at various periods, applied to SDS-PAGE, transferred to nylon membranes, and then immunostained with biotinylated anti-(lipocalin-type PGD synthase) IgG. The $M_{\mathrm{r}}$ values of immunoreactive proteins are shown at left.

PGD synthase, but no hybridization was observed for hematopoietic-type PGD synthase (Fig. 5C). The expression levels of PGD synthase in retina were relatively lower than those of the arachnoid membrane and total brain RNA. Thus, it can be
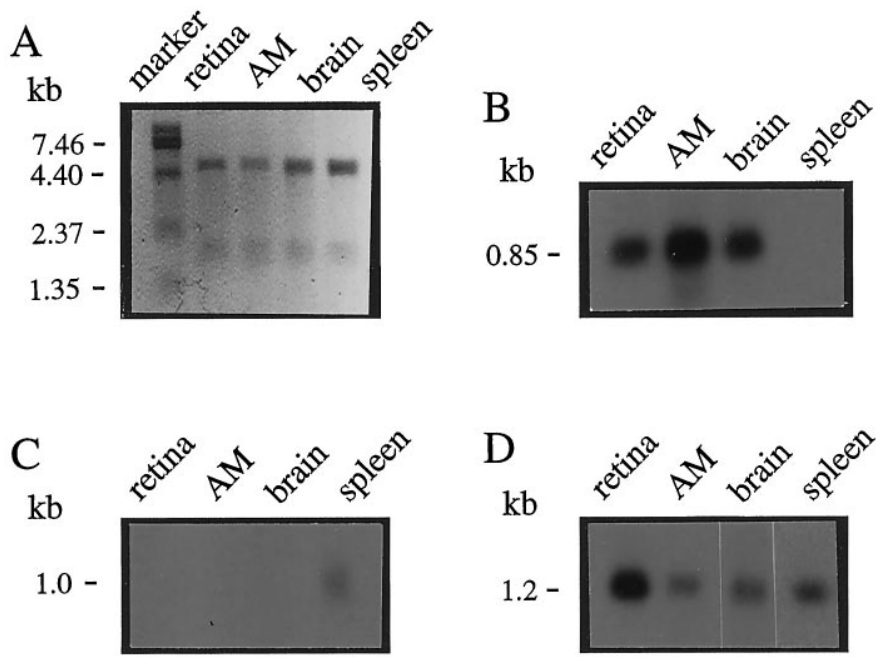

Figure 5. Northern blot analysis of total RNA from rat retina, arachnoid membrane $(A M)$, brain, and spleen after denaturing agarose gel electrophoresis. $A$, Ethidium bromide staining ( $2 \mu \mathrm{g}$ per lane). $B$, Detection of lipocalin-type PGD synthase mRNA (2 $\mu \mathrm{g}$ per lane). $C$, Detection of hematopoietic-type PGD synthase mRNA (20 $\mu \mathrm{g}$ per lane). $D$, Detection of GAPDH mRNA ( $2 \mu \mathrm{g}$ per lane). 
inferred that the PGD synthase mRNA present in retinal tissues (Fig. $1 G, H$ ) originated from RPE.

\section{DISCUSSION}

\section{The lipocalin-type PGD synthase as a lipophilic substance transporter in the IPM}

Lipocalin-type PGD synthase is a member of the superfamily composed of the lipophilic molecule transporters, and recent work has demonstrated its ability to bind retinoic acid and retinal with affinities comparable to those of other retinoid-binding proteins (Tanaka et al., 1995). IPM participates in a very active retinoid recycling system to replenish the photosensitive chromophores of rhodopsin within photoreceptor outer segments. In fact, at least four retinoid-binding proteins that participate in the visual cycle have been identified in association with photoreceptors, IPM, and RPE (Bok, 1985). Moreover, the supply of retinoids from systemic circulation is strictly controlled by the bloodretina barrier at the RPE level, demonstrating the importance of this layer of cells to the overall health and maintenance of retina (Gordon and Bazan, 1996). PGD synthase may also be involved in the transport of retinoids or retinoid-like compounds through IPM toward photoreceptor cells. For example, one lipophilic candidate as a ligand for this transport enzyme is docosahexanoic acid, an essential fatty acid that is supplied systemically to retina by liver (Scott and Bazan, 1989) for RPE and photoreceptor cells (Gordon and Bazan, 1990, 1993). Interestingly, this molecule is also linked to a recycling pathway within the retina (Gordon et al., 1992), and interphotoreceptor retinoid binding protein (IRBP) has been implicated as a carrier of this essential fatty acid (Bazan et al. 1985; Bazan, 1990).

\section{The lipocalin-type PGD synthase as an enzyme in the eye}

$\mathrm{PGD}_{2}$ is a major prostaglandin formed in the eye (Birkle and Bazan, 1984), and PGD synthase has the highest activity among other prostaglandin synthases in ocular tissues, especially within the retina (Goh et al., 1987). Recently, the human $\mathrm{PGD}_{2}$ receptor was cloned, and its mRNA tissue distribution showed the highest abundance in retina (Boie et al., 1995), although its specific cellular localization in retina has not yet been shown. These observations, together with our findings, indicate that $\mathrm{PGD}_{2}$ may be important in RPE function. However, to answer the questions about $\mathrm{PGD}_{2}$ production in retina, it will be necessary to locate cycloxygenases 1 and 2, which catalyze the conversion of arachidonic acid to $\mathrm{PGH}_{2}$ at the cellular level in retina. Because $\mathrm{PGH}_{2}$ has a very short half-life in aqueous solutions, the cyclooxygenases should be very closely associated with PGD synthase as part of the $\mathrm{PGD}_{2}$-producing pathway.

There are structural and functional similarities between retinal and CNS lipocalin-type PGD synthases. This and its mRNA are found in epithelial cells of the arachnoid membranes and choroid plexus in brain (Urade et al., 1993) and are secreted into CSF within its closed compartment in large amounts (Hoffman et al., 1993; Watanabe et al., 1994). RPE and the leptomeninges are ontogenically and functionally analogous to each other, forming the blood-retina and blood-brain barriers with tight junctions between cells to seal the closed compartments of retina and brain. Furthermore, although we found the immunoreactive protein of this enzyme in photoreceptor cells, no mRNA could be detected in these cells (Fig. 1G,H). A similar observation has also been reported in rat brain, in which immunoreactivity was detected in most neurons of infant rats and several neurons in layers I-II of the cerebral cortex of adult rats (Urade et al., 1987; Urade et al., 1993), but no mRNA was detected in these neurons (Urade et al., 1993). Photoreceptor cells, which are highly specialized neurons, seem to respond in a similar manner as the immunoreactive neurons detected in brain. Therefore, these results suggest that lipocalin-type PGD synthase is secreted by brain epithelial cells into the closed compartment containing the CSF and by retinal RPE cells into the IPM, followed by subsequent uptake from these compartments by specific neurons.

In this study, we have shown by enzyme activity, Western blot analysis (Fig. 2), immunofluorescence staining (Fig. 1A-F), and in situ hybridization (Fig. $1 G, H$ ) that lipocalin-type PGD synthase is highly enriched in RPE cells and accumulates in large amounts within the IPM. Also, glycosylation of the PGD synthase moiety may be associated with the process of mobilization from the endoplasmic reticulum (the site of synthesis) to the IPM, where the most abundant component appears to be the highly glycosylated form. PGD synthase activity and protein levels found in IPM and RPE soluble fractions positively correlate (despite different glycosylation levels), in agreement with previous findings, indicating that the levels of glycosylation of the PGD synthase moiety do not affect enzymatic activity (Urade et al., 1989). Because retina does not express PGD synthase mRNA (Fig. $1 G, H$ ) and contains only a glycosylated form of PGD synthase (Fig. 3), these observations strongly suggest directional movement from the RPE membrane-bound fraction (site of synthesis) and the RPE cytosolic fraction (transport), through the IPM soluble fraction (transport), to photoreceptors (Fig. 1E,F).

Among the many questions that arise from the findings reported in this paper is the possible presence of a lipocalin-type PGD synthase selective uptake mechanism (or receptor) in photoreceptors. Is this located in the inner segments? What is the nature of the molecule, if any, that is being transported? Besides retinoic acid and/or docosahexanoic acid, can $\mathrm{PGD}_{2}$ itself be attached to the enzyme of its synthesis and then be intercellularly transported to the photoreceptor cells where it may elicit a function? This sequestration of $\mathrm{PGD}_{2}$ can be a regulatory mechanism to prevent further metabolism to $\mathrm{PGJ}_{2}$, a potent bioactive modulator (Forman et al., 1995; Kliewer et al., 1995). Moreover, lipocalin-type PGD synthase may be a unidirectional carrier molecule from RPE to the photoreceptor, because it is synthesized in RPE. IRBP, on the other hand, is synthesized in photoreceptors and then secreted into the IPM (Pepperberg et al., 1993). One may argue that carrier molecules present in the IPM could transport ligands in either direction.

Our study suggests that lipocalin-type PGD synthase may have multiple functions, acting as both enzyme and intercellular transporter, and the high concentration of lipocalin-type PGD synthase in the IPM strongly argues that this molecule plays an important function in retina. Finally, we have shown that retina-RPE can serve as an excellent model to study the function and metabolism of $\mathrm{PGD}_{2}$ and the bifunctional ability of the lipocalin-type PGD synthase as a $\mathrm{PGD}_{2}$-producing enzyme and a potential lipophilic ligand transporter.

\section{REFERENCES}

Bazan NG, Reddy TS, Redmond TM, Wiggert B, Chader GJ (1985) Endogenous fatty acids are covalently and noncovalently bound to interphotoreceptor retinoid-binding protein in the monkey retina. J Biol Chem 260:13677-13680.

Bazan NG (1990) Supply of n-3 polyunsaturated fatty acids and their significance in the central nervous system. In: Nutrition and the brain (Wurtman RJ, Wurtman JJ, eds), pp 1-24. New York: Raven. 
Bensadoun A, Weinstein D (1976) Assay of proteins in the presence of interferring materials. Anal Biochem 70:241-250.

Birkle DL, Bazan NG (1984) Lipozygenase and cyclooxygenase reaction products and incorporation into glycerolipids of radiolabeled arachidonic acid in the bovine retina. Prostaglandins 27:203-216.

Boie Y, Sawyer N, Slipetz DM, Metters KM, Abramovitz M (1995) Molecular cloning and characterization of the human prostanoid DP receptor. J Biol Chem 270:18910-18916.

Bok D (1985) Retinal photoreceptor-pigment epithelium interactions. Friedenwald lecture. Invest Ophthalmol Vis Sci 26:1659-1694.

Chomczynski P, Sacchi N (1987) Single-step method of RNA isolation by acid guanidinium thiocyanate-phenol-chloroform extraction. Anal Biochem 162:156-159.

Clausen J (1961) Proteins in normal cerebrospinal fluid not found in serum. Proc Soc Exp Biol Med 107:170-172.

Forman BM, Tontonoz P, Chen J, Brun RP, Spiegelman BM, Evans RM (1995) 15-Deoxy-delta ${ }^{12,14}$-prostaglandin $\mathbf{J}_{2}$ is a ligand for the adipocyte determination factor PPAR ${ }^{\mathrm{Y}}$. Cell 83:803-812.

Goh Y, Urade Y, Fujimoto N, Hayaishi O (1987) Content and formation of prostaglandins and distribution of prostaglandin-related enzyme activities in the rat ocular system. Biochem Biophys Res Commun 921:302-311.

Gordon WC, Bazan NG (1990) Docosahexaenoic acid utilization during rod photoreceptor cell renewal. J Neurosci 10:2190-2204.

Gordon WC, Bazan NG (1993) Visualization of $\left[{ }^{3} \mathrm{H}\right]$ docosahexaenoic acid trafficking through photoreceptors and retinal pigment epithelium by electron microscope autoradiography. Invest Ophthalmol Vis Sci 34:2402-2411.

Gordon WC, Bazan NG (1996) Cellular organization and biochemistry of the retina. In: Ocular biochemistry (Harding J, ed). London: Chapman and Hall.

Gordon WC, Rodriguez de Turco EB, Bazan NG (1992) Retinal pigment epithelial cells play a central role in the conservation of docosahexaenoic acid by photoreceptor cells after shedding and phagocytosis. Curr Eye Res 11:73-83.

Gordon WC, Beuckmann CT, Marcheselli VL, Kanaoka Y, Gerashchenko DY, Eguchi N, Urade Y, Hayaishi O, Bazan NG (1996) Lipocalin type prostaglandin $\mathrm{D}$ synthase is located in retinal pigment epithelium. Invest Ophthalmol Vis Sci 37:S385.

Hayaishi O (1991) Molecular mechanisms of sleep-wake regulation: roles of prostaglandins D1 and E2. FASEB J 5:2575-2581.

Hoffman A, Conradt HS, Gross G, Nimtz M, Lottspeich F, Wurster U (1993) Purification and chemical characterization of $\beta$-trace protein from human cerebrospinal fluid: its identification as prostaglandin D synthase. J Neurochem 61:451-456.

Kliewer SA, Lenhard JM, Willson TM, Patel I, Morris DC, Lehmann JM (1995) A prostaglandin $J_{2}$ metabolite binds peroxisome proliferatoractivated receptor gamma and promotes adipocyte differentiation. Cell 83:813-819.

Lowry OH, Rosebrough NJ, Farr AL, Randall RJ (1951) Protein measurement with the folin phenol reagent. J Biol Chem 193:265-275.
Marcheselli VL, Gordon WC, Stellingworth MA, Beuckmann CT, Urade Y, Hayaishi O, Bazan NG (1996) Lipocalin type prostaglandin D synthase is secreted into the interphotoreceptor matrix from the retinal pigment epithelium. Invest Ophthalmol Vis Sci 34:S385.

Nagata A, Suzuki Y, Igarashi M, Eguchi N, Toh H, Urade Y, Hayaishi O (1991) Human brain prostaglandin D synthase has been evolutionarily differentiated from lipophilic-ligand carrier proteins. Proc Natl Acad Sci USA 88:4020-4024.

Pepperberg DR, Okajima T-LI, Wiggert B, Ripps H, Crouch RK, Chader GJ (1993) Interphotoreceptor retinoid-binding protein. Mol Neurobiol 7:61-85.

Piatigorsky J, O'Brien WE, Norman BL, Kalumuck K, Wistow GJ, Borras T, Nickerson JM, Wawrousek EF (1988) Gene sharing by $\delta$-crystallin and ardininosuccinate lysase. Proc Natl Acad Sci USA 85:3479-3483.

Piatigorsky J, Wistow GJ (1989) Enzyme/crystallins: gene sharing as an evolutionary strategy. Cell 57:197-199.

Scott BL, Bazan NG (1989) Membrane docosahexanoate is supplied to the developing brain and retina by the liver. Proc Natl Acad Sci USA 86:2903-2907.

Tachibana M, Fex J, Urade Y, Hayaishi O (1987) Brain-type prostaglandin D synthetase occurs in the rat cochlea. Proc Natl Acad Sci USA 84:7677-7680.

Tanaka T, Kikuchi M, Kimura H, Eguchi N, Urade Y, Hayaishi O, Toh H (1995) $\mathrm{Cys}^{65}$ is an essential thiol for glutathione-independent prostaglandin D synthase. J Neurochem 65S:S182.

Ujihara M, Urade Y, Eguchi N, Hayashi H, Ikai K, Hayaishi O (1988) Prostaglandin D2 formation and characterization of its synthetases in various tissues of adult rats. Arch Biochem Biophys 260:521-531.

Urade Y, Fujimoto N, Hayaishi O (1985) Purification and characterization of rat brain prostaglandin D synthetase. J Biol Chem 260:12410-12415.

Urade Y, Fujimoto N, Kaneko T, Konishi A, Mizuno N, Hayaishi O (1987) Postnatal changes in the localization of prostaglandin D synthetase from neurons to oligodendrocytes in the rat brain. J Biol Chem 262:15132-15136.

Urade Y, Nagata A, Suzuki Y, Fujii Y, Hayaishi O (1989) Primary structure of rat brain prostaglandin D synthetase deduced from cDNA sequence. J Biol Chem 264:1041-1045.

Urade Y, Kitahama K, Ohishi H, Kaneko T, Mizuno N, Hayaishi O (1993) Dominant expression of mRNA for prostaglandin D synthase in leptomeninges, choroid plexus, and oligodendrocytes of the adult rat brain. Proc Natl Acad Sci USA 90:9070-9074.

Urade Y, Tanaka T, Eguchi N, Kukuchi M, Kimura H, Toh H, Hayaishi O (1995a) Structural and functional significance of cysteine residues of glutathione-independent prostaglandin D synthase. Identification of Cys $^{65}$ as an essential thiol. J Biol Chem 270:1422-1428.

Urade Y, Watanabe K, Hayaishi O (1995b) Prostaglandin D, E, and F synthetases. J Lipid Mediator Cell Signaling 12:257-273.

Watanabe K, Urade Y, Mäder M, Murphy C, Hayaishi O (1994) Identification of $\beta$-trace as prostaglandin D synthase. Biochem Biophys Res Commun 203:1110-1116. 